\title{
A QUR'ANIC CONCEPT OF SADNESS: Implication For CBT-Q Content Supplement (Part 1)
}

\author{
Nur Afifah binti Abas \\ School of Humanities, Universiti Sains Malaysia, Penang, Malaysia \\ Email: afifabas@student.usm.my
}

\begin{abstract}
This study develops a Qur'anic culturally-adapted psychoeducational content supplement on sadness (huzn) for the Cognitive Behavioral Therapy (CBT) Approach in preventing or treating depression among Muslim clients. The content of the concept derived from a Qur'anic Thematic Exegetical Analysis (al-Tafsìr al$\left.M a w d u^{\prime} \bar{\imath}\right)$. It is a support towards religious psychotherapy from the Islamic Studies field. CBT approach is compatible with the religion of Islam provided complying with the Islamic methodologies e.g., the epistemological aspects of constructs/absolute or relative reality. It is educationally important for Muslims' existential needs to resiliently face the challenges of life in general.
\end{abstract}

Keywords: Culturally-adapted psychoeducation (CaPE), Qur'anic Thematic Exegetical Analysis, Existential Needs, Existential Resiliency, Islamic Cognitive-Behavioral Therapy (CBT-I), and Qur'anic CognitiveBehavioral Therapy (CBT-Q).

DOI: https://doi.org/10.20414/ujis.v25i1.438

\section{Introduction}

LOSS is among the main themes emerged in the literature postcovid-19 outbreak. Loss influences us to bodily and emotionally react against any mishap happened to us especially in processing and understanding the lost health, loved one/s, job, house, normal life before the pandemic, etc. ${ }^{1}$ These unexpected sudden miseries are overwhelming compared to our normal life. The overloaded mixed undesirable feelings and emotions naturally afflict people. For some, this awkward situation is unbearable, thus, just opted

1 Andrew T. Gloster et al., "Impact of COVID-19 Pandemic on Mental Health: An International Study," ed. Joel Msafiri Francis, PLOS ONE 15, no. 12 (December 31, 2020): e0244809, https://dx.plos.org/10.1371/journal.pone.0244809. 
the worst to commit suicide where the trend is ascending. ${ }^{2}$ But suicide is sinful for Muslims, thus, we need to extend help to fortify our resilience in the trying time.

Therefore, mental health practice has to play as important role as the primary medical care. The trend has relaxed on the stigma on the mental health. It even demands therapists to adapt their clients' religious and spiritual affiliations in treating or preventing mental illness. ${ }^{3}$ Human beings especially Muslims (who believe) in the fact that we are innately created having undeniable existential need of connecting to the Supreme Being: The God/Allah when exposed to great dangers. Indeed, this Qur'anic verse literally and metaphorically illustrated such dire need:

"He is the One who Enables you to travel through the land and the sea. And it so happens that you are on ships, sailing with a favorable wind, to the passengers' delight. Suddenly, the ships are overcome by a windstorm and those on board are overwhelmed by waves from every side, and they assume they are doomed. They cry out to Allah 'alone' in sincere devotion, "If You save us from this, we will certainly be grateful." [Chapter Jonas (Sūrah Yūnus) 10: verse no. 22]

The trend shift was evident after the tragedy of 9/11 in 2001 . Suddenly, more studies started pouring in the literature on the role of religion and spirituality in coping with major life stressors e.g. RCOPE research. ${ }^{4}$ The researchers found that positive religious coping methods help people to cope better with the adversary befell them. ${ }^{5}$ Furthermore, they found similar pattern in all

2 Vikram Thakura and Anu Jain, "COVID 2019-Suicides: A Global Psychological Pandemic," Brain, Behavior, and Immunity 88 (2020): 952-953, $\begin{array}{lll}\text { accessed November 2020, } & \text { 6, }\end{array}$ https://www.ncbi.nlm.nih.gov/pmc/articles/PMC7177120/pdf/main.pdf.

3 Simon Dein, "Religious Healing and Mental Health," Mental Health, Religion $\mathcal{E}$ Culture 23, no. 8 (September 13, 2020), accessed December 8, 2020, https://www.tandfonline.com/doi/full/10.1080/13674676.2020.1834220.

4 Kenneth Pargament, Margaret Feuille, and Donna Burdzy, "The Brief RCOPE: Current Psychometric Status of a Short Measure of Religious Coping" 2 (2011): 51-76, accessed October 21, 2020, www.mdpi.com/journal/religionsArticle.

${ }^{5}$ Scott, T. Walters and Melanie E. Bennett, “Assesing Clients' Spirituality and Religious Behavior: Recommendations for Research and Practice in Mental Health," The Behavior Therapist 23, no. 4 (2000): 79-90. 
religious and spiritual affiliations. ${ }^{6}$

However, there are religious or spiritual beliefs that are if inaccurately ingrained or misperceived may turn to become negative religious coping, which will be highly correlated with inner psychical conflict (thus, cognitively too) and disharmony among oneself with own self, or/and other fellow humans, or/and the Divine Power. Empirically significant, its Negative Religious Coping subscale is a strong predictor of health problem(s). ${ }^{7}$

It reflects the role of religious and spiritual beliefs that promotes resilience (e.g., hardy personality) in facing life challenges. ${ }^{8}$ For example, among the life challenges that can develop into depression over lifespan are unfortunate childhood history, perception of deprived social support, present life event(s) stressor(s), a vulnerable personality style, and previous depressive illness. ${ }^{9}$

Actually, religious/spiritual coping provides a ready belief system to cognitively accommodate adjustment intelligence while experiencing the mishap prepared..$^{10}$ But the more important part is the content of the belief system that will gradually develops

${ }^{6}$ Harold G. Koenig, Faten Al Zaben, and Doaa Ahmed Khalifa, "Religion, Spirituality and Mental Health in the West and the Middle East," Asian Journal of Psychiatry 5, no. 2 (June 2012), accessed December 26, 2020, https://pdf.sciencedirectassets.com/277359/1-s2.0-S1876201812X00030/1-s2.0S1876201812000767/main.pdf.

${ }^{7}$ Pargament, Feuille, and Burdzy, “The Brief RCOPE: Current Psychometric Status of a Short Measure of Religious Coping"; Walters and Bennett, "Assesing Clients' Spirituality and Religious Behavior: Recommendations for Research and Practice in Mental Health"; Zahra Taheri-Kharameh et al., "Negative Religious Coping, Positive Religious Coping, and Quality of Life Among Hemodialysis Patients," Nephrourol Mon 8, no. 6 (2016): 38009, accessed December 22, 2020, https://www.ncbi.nlm.nih.gov/pmc/articles/PMC5120233/pdf/num-08-0638009.pdf.

${ }^{8}$ Kira E. Riehm et al., "Association between Psychological Resilience and Changes in Mental Distress during the COVID-19 Pandemic," Journal of Affective Disorders 282 (March 2021): 381-385, https://linkinghub.elsevier.com/retrieve/pii/S016503272033161X.

9 Candice O'Sullivan, "The Psychosocial Determinants of Depression," The Journal of Nervous and Mental Disease 192, no. 9 (September 2004): 585-594, accessed October 21, 2020, http://journals.lww.com/00005053-200409000-00002.

${ }^{10}$ Harold G. Koenig and David B. Larson, "Religion and Mental Health: Evidence for an Association," International Review of Psychiatry, 2001. 
invincible resiliency within the copers' psyche especially as a protective mechanism. In the long run, they are also able to shield the immune system from being deteriorated, so, will gracefully experience ageing. ${ }^{11}$

\section{Muslim Clients Prefer Islamic Psychotherapy}

Basically, the Muslim clients also will prefer their clergies (imams) or respected elderlies to counsel them due to being uncomfortable with Western psychotherapy ${ }^{12}$ with alien ideas unfamiliar to their Islamic cognitive structure of belief system. ${ }^{13}$ Consequently, the trend evolves further in incorporating Islamic beliefs and practice into the mental health practice for religious/spiritual oriented clients e.g., Religious/Spiritual Cognitive-Behavioral Therapy (R/S CBT) Approach. ${ }^{14}$

${ }^{11}$ Joanna Malone and Anna Dadswell, "The Role of Religion, Spirituality and/or Belief in Positive Ageing for Older Adults," Geriatrics 3, no. 28 (2018): 116, accessed October 23, 2020, www.mdpi.com/journal/geriatrics.

${ }_{12}$ Wahiba Abu-Ras, Ali Gheith, and Francine Cournos, "The Imam's Role in Mental Health Promotion: A Study at 22 Mosques in New York City's Muslim Community," Journal of Muslim Mental Health 3, no. 2 (2008): 155-176, accessed October 18 ,

2020, https://www.tandfonline.com/doi/abs/10.1080/15564900802487576; Osman M. Ali, Glen Milstein, and Peter M. Marzuk, "The Imam's Role in Meeting the Counseling Needs of Muslim Communities in the United States," Psychiatric Services 56, no. 2 (February 2005): 202-205, accessed January 23, 2021, https://ps.psychiatryonline.org/doi/pdf/10.1176/appi.ps.56.2.202.

${ }^{13}$ Farooq Naeem et al., "Views of Depressed Patients in Pakistan Concerning Their Illness, Its Causes, and Treatments," Qualitative Health Research 22, no. 8 (August 15, 2012), accessed December 21, 2020, https://journals.sagepub.com/doi/pdf/10.1177/1049732312450212; Farooq Naeem et al., "Using Cognitive Behaviour Therapy with South Asian Muslims: Findings from the Culturally Sensitive CBT Project" 27, no. 3 (2015): 233-246, accessed December 21, 2020, https://doi.org/10.3109/09540261.2015.1067598.

14 Haifa Mohammad Saleh Algahtani et al., "Cultural Adaptation of Cognitive Behavioural Therapy (CBT) for Patients with Depression and Anxiety in Saudi Arabia and Bahrain: A Qualitative Study Exploring Views of Patients, Carers, and Mental Health Professionals" 12 (2020): 1-17, accessed October 19, 2020,

https://www.cambridge.org/core/terms.https://doi.org/10.1017/S1754470X1900028 XDownloadedfromhttps://www.cambridge.org/core. 
Beshai found that CBT is naturally workable with religions and spirituality, ${ }^{15}$ as Beck asserted that it is integrative in nature. ${ }^{16}$ Comparatively, he further benchmarked the CBT application between Muslim and non-Muslim Western clients where it is equally applicable. ${ }^{17}$

\section{Psychotherapists' Dilemmas in Adapting to Muslim Clients}

Since religion and spirituality returned home to the psychotherapy, the therapists were busy educating themselves religious and spiritual orientation ${ }^{18}$ e.g., considering potential belief that can motivate the desired modification on the interaction among thoughts-emotions-actions. ${ }^{19}$ As Beck stated: "It's not the situations in our lives that cause distress, but rather our interpretations of those situation" 20 .

\section{Misperceptions in Understanding Islam}

Further down the road in adapting therapy to the new trend, non-Muslim psychologists misperceived information about Islam for example Beshai reported Smith said: "the Qur'an is to Muslims what Christ is to Christians". Whereby, actually the Holy Qur'an is to Muslims like the Holy Bible (Injill) is to Christians. Or contrarily

${ }^{15}$ S., Beshai, K. S. Dobson, and A. Adel, "Cognition and Dysphoria in Egypt and Canada: An Examination of the Cognitive Triad.," Canadian Journal of Behavioural Science 44, no. 1 (2012): 29-39, accessed October 13, 2020, https://psyc.ucalgary.ca/manageprofile/sites/psyc.ucalgary.ca.manageprofile/files /unitis/publications/1-5446669/Beshai_Dobson_Adel_2012.pdf.

${ }^{16}$ B. A. Alford and A. T. Beck, The Integrative Power of Cognitive Therapy (New York: The Guilford Press, 1997).

17 Shadi Beshai, Cameron M. Clark, and Keith S. Dobson, "Conceptual and Pragmatic Considerations in the Use of Cognitive-Behavioral Therapy with Muslim Clients," Cognitive Therapy and Research 37, no. 1 (February 2013): 197206, http://link.springer.com/10.1007/s10608-012-9450-y.

18 Cassandra Vieten et al., "Spiritual and Religious Competencies for Psychologists.," Psychology of Religion and Spirituality 5, no. 3 (2013): 129-144, http://doi.apa.org/getdoi.cfm?doi=10.1037/a0032699.

${ }^{19}$ Beshai, Clark, and Dobson, "Conceptual and Pragmatic Considerations in the Use of Cognitive-Behavioral Therapy with Muslim Clients."

${ }^{20}$ Aaron T Beck, "The Past and Future of Cognitive Therapy," The Journal of Psychotherapy Practice and Research 6, no. 4 (1997): 276-284, accessed November 16, 2020, https://www.ncbi.nlm.nih.gov/pmc/articles/PMC3330473/pdf/jp64276.pdf. 
can also be adjusted as it is the Prophet Muhammad s.a.w. is to Muslims like Christ (the Prophet $c \bar{I} s \bar{a}$ a.s.) is to Christians.

These misperceptions show a need for more direct involvement from academics of Islamic studies with adequate shared background in the field of psychology and its therapeutic treatments to supply for shortage of relevant reference. ${ }^{21}$ So far, Islamically integrated psychotherapy are underrepresented by the people who involved directly with the religious service/studies e.g., clergies (Islamic scholars or imams).22 Evidently, e.g., Beck

21 Hisham Abu Raiya and Kenneth I. Pargament, “Empirically Based Psychology of Islam: Summary and Critique of the Literature," Mental Health, Religion $\mathcal{E}$ Culture 14, no. 2 (February 2011): 93-115, accessed October 18, 2020, http://www.tandfonline.com/doi/abs/10.1080/13674670903426482; Jeffrey E. Barnett and W. Brad Johnson, "Integrating Spirituality and Religion Into Psychotherapy: Persistent Dilemmas, Ethical Issues, and a Proposed DecisionMaking Process," Ethics E Behavior 21, no. 2 (March 28, 2011), accessed December 2, https://www.tandfonline.com/doi/pdf/10.1080/10508422.2011.551471?needAccess =true; Matthew Breuninger et al., "Psychologists and Clergy Working Together: A Collaborative Treatment Approach for Religious Clients," Journal of Spirituality in Mental Health 16, no. 3 (2014): 149-170, accessed October 19, 2020, https://www.tandfonline.com/action/journalInformation?journalCode=wspi20;

Ghazala Mir et al., "Delivering a Culturally Adapted Therapy for Muslim Clients with Depression," The Cognitive Behaviour Therapist 12 (April 12, 2019): e26, https://www.cambridge.org/core/product/identifier/S1754470X19000059/type/jour nal_article; Shaista Meer and Ghazala Mir, "Muslims and Depression: The Role of Religious Beliefs in Therapy," Journal of Integrative Psychology and Therapeutics 2, no. 1 (2014), accessed November 30, 2020, https://www.hoajonline.com/journals/pdf/2054-4723-2-2.pdf; Michelle J. Pearce et al., "Religiously Integrated Cognitive Behavioral Therapy: A New Method of Treatment for Major Depression in Patients with Chronic Medical Illness.," Psychotherapy 52, no. 1 (2015), accessed December 1, 2020, https://doi.apa.org/doiLanding?doi=10.1037\%2Fa0036448.

${ }^{22}$ Breuninger et al., "Psychologists and Clergy Working Together: A Collaborative Treatment Approach for Religious Clients"; Walaa M Sabry and Adarsh Vohra, "Role of Islam in the Management of Psychiatric Disorders," Indian Journal of Psychiatry 55, no. 6 (2013): 205-214, accessed November 30, 2020, http://www.indianjpsychiatry.org/text.asp?2013/55/6/205/105534; Amber Haque and Hooman Keshavarzi, "Integrating Indigenous Healing Methods in Therapy: Muslim Beliefs and Practices," International Journal of Culture and Mental Health 7, no. 3 (2014): 297-314, accessed October 18, 2020, https://www.tandfonline.com/doi/abs/10.1080/17542863.2013.794249. 
Institute also responded that it does not have a training course for Islamically adapted CBT approach. ${ }^{23}$

It is undeniable that existing religious belief and value systems are usually based on certain sacred scriptures of respective religions where therapists need to gain some necessary knowledge to apply religious therapy. ${ }^{24}$ Even the psychotherapists themselves confessed that their training was absent of religious training and theirs may differ clients' religious affiliations. They also complained the fact that they are also not clergies/pastors/religious scholars or authorities themselves but 'therapists'. Thus, they need collaboration from those in religious service or studies. ${ }^{25}$ Nevertheless, religious sources belong to cultural-sensitive sciences that need special care in handling it due to its revered sources, special meaning attached to it and established fundamental principles or else, will unnecessarily offend the clients. $^{26}$

It is more complicated when they need to use alternative method in intervening clients' faulty ideas or incomplete coverage on a certain issue that had influenced their interpretations of the

23 Grace Barry, "Personal Communication - Asking on CBT Courses for Muslim Clients," Beck Institute (USA, 2020), accessed December 1, 2020, gmail.com.

24 Barnett and Johnson, "Integrating Spirituality and Religion Into Psychotherapy: Persistent Dilemmas, Ethical Issues, and a Proposed DecisionMaking Process"; Lance D Laird, Mona M Amer, and Elizabeth D Barnett, "Muslim Patients and Health Disparities in the UK and the US," Arch Dis Child 92 (2007): 922-926, www.archdischild.com.

25 Dein, "Religious Healing and Mental Health"; Barnett and Johnson, "Integrating Spirituality and Religion Into Psychotherapy: Persistent Dilemmas, Ethical Issues, and a Proposed Decision-Making Process"; Breuninger et al., "Psychologists and Clergy Working Together: A Collaborative Treatment Approach for Religious Clients"; American Counseling Association, Integrating Spirituality and Religion into Counseling: A Guide to Competent Practice, ed. Craig S. Cashwell and J. Scott Young, 2nd ed. (Alexandria: American Counseling Association, 2011), accessed December 2, 2020, https://www.counseling.org/Publications/FrontMatter/72906-FM.PDF.

${ }^{26}$ Malik Babikir Badri, Contemplation: An Islamic Psychospiritual Study, ed. Abdul Malik Lu'lu'a, 2nd ed. (Kuala Lumpur : Medeena Books, 2000). 
Islamic beliefs like in maladaptive cognitions $\operatorname{cases}^{27}$ that caused self-blaming, ${ }^{28}$ which are rooted in negative religious coping of believing ${ }^{29}$ e.g., being sad is a moral disorder ${ }^{30}$ like "divine retribution", thus, labelled ${ }^{31}$ as "lack of faith" or being "an inadequate good Muslim". ${ }^{32}$

Sometimes Muslim clients themselves are not aware that what they believe is incongruent or not with the authentic Islamic teachings. They may be influenced by what is culturally believed about sadness or depression..$^{33}$ These problems are gaining more attention for Islamic solutions where there is a need to use the Qur'an directly to gain better trust and confidence of the clients to comply with the treatments and finally achieve its therapeutic goals. ${ }^{34}$ So, Islamically speaking, it is a social duty (fardu kifāyah) for those belong to the Islamic Studies fields/services to represent this field like the pastoral/chaplaincy psychology is prosperously developing in the West as a scientific benchmark.

\footnotetext{
${ }^{27}$ Ayse Ciftci, Nev Jones, and Patrick W Corrigan, Mental Health Stigma in the Muslim Community, Journal of Muslim Mental Health ISSN1556-4908, vol. 7, 2013, accessed December 22, 2020, http://hdl.handle.net/2027/spo.10381607.0007.102.

${ }^{28}$ Erdem Pulcu, Roland Zahn, and Rebecca Elliott, "The Role of Self-Blaming Moral Emotions in Major Depression and Their Impact on Social-Economical Decision Making," Frontiers in Psychology 4 (2013), http://journal.frontiersin.org/article/10.3389/fpsyg.2013.00310/abstract.

${ }^{29}$ Koenig and Larson, "Religion and Mental Health: Evidence for an Association"; Abu Raiya and Pargament, "Empirically Based Psychology of Islam: Summary and Critique of the Literature"; Taheri-Kharameh et al., "Negative Religious Coping, Positive Religious Coping, and Quality of Life Among Hemodialysis Patients."

${ }^{30}$ Maev Conneely, Paul Higgs, and Joanna Moncrieff, "Medicalising the Moral: The Case of Depression as Revealed in Internet Blogs," Social Theory $\mathcal{E}$ Health (June 4, 2020), http://link.springer.com/10.1057/s41285-020-00141-1.

${ }^{31}$ Ciftci, Jones, and Corrigan, Mental Health Stigma in the Muslim Community, vol. 7, p. .

32 Karim Mitha, "Conceptualising and Addressing Mental Disorders amongst Muslim Communities: Approaches from the Islamic Golden Age," Transcultural Psychiatry 57, no. 6 (December 15, 2020): 763-774, http://journals.sagepub.com/doi/10.1177/1363461520962603.

${ }^{33}$ Ibid.

${ }^{34}$ Beshai, Clark, and Dobson, "Conceptual and Pragmatic Considerations in the Use of Cognitive-Behavioral Therapy with Muslim Clients."
} 


\section{Cognitive Behavior Therapy (CBT)}

Cognitive-Behavioral Therapy (CBT) is a conversational psychotherapy, basically between a psychotherapist and a client focuses on cognition. In a professional mental health counseling setting, a therapist plans the treatments in a structured way, which are divided through certain agreed number of sessions that need commitment from the client. The main cognitive model believes that "the way individuals perceive a situation is more closely connected to their reaction than the situation itself". ${ }^{35}$

Historically, Beck serendipitously founded the cognitive behavioral therapy (CBT) methodology when he was observing a depressed client's thinking patterns. He continued observing all his clients to see similar thinking patterns to other than depressed problems until he could categorize their patterns of thoughts belong to mental illness. ${ }^{36}$ Thus far, the CBT is still robustly crowned among the best evidence-based approach. ${ }^{37}$ What is special with CBT is that it can be applied as preventive measure via psychoeducational programs, which gives hope for collective broader health intervention rather than the limited one-to-one treatment session, ${ }^{38}$ which is a risky act during the pandemic.

The most common mental health problem, namely depression, becomes overwhelmed due to the sudden outbreak of the COVID19 pandemic. It was already alarming in the reported prepandemic Global Burden of Diseases Study 2019 (GBD 2019). ${ }^{39}$ It

35 Steven C. Hayes and Stefan G. Hofmann, "The Third Wave of Cognitive Behavioral Therapy and the Rise of Process-Based Care," World Psychiatry 16, no. 3 (October 1, 2017): 245-246, accessed November 3, 2020, http://doi.wiley.com/10.1002/wps.20442.

${ }^{36}$ Beck, "The Past and Future of Cognitive Therapy."

37 Xavier Noel et al., "Why Cognitive Behavioral Therapy Is the Current Gold Standard of Psychotherapy," Frontiers in Psychiatry 9 (2018): 1-3, accessed November 10, 2020, www.frontiersin.org.

${ }^{38}$ Aisha Hamdan, "Cognitive Restructuring: An Islamic Perspective," Journal of Muslim Mental Health 3, no. 1 (March 2008): 99-116.

${ }^{39}$ Global Health Metrics, “GBD Summaries: Depressive Disorders - Level 3 Cause," The Lancet: Global Burden of Diseases 2019 (2020): 1-2, accessed January 7, 2021, https://www.thelancet.com/pbassets/Lancet/gbd/summaries/diseases/depressive-disorders.pdf. 
highlights more the role of religion in healing it, or better, at preventing it. ${ }^{40}$

Depression is different from sadness from the aspect of time that depression stalks all walk of the depressed clients' life and thinking unlike sadness, which is induced temporarily by undesirable event like being upset or unmet expectation or lost someone/something meaningful but does not prolong to become a pathology. ${ }^{41}$

Meanwhile from the behavioral signs of depression, one may start to experience difficulty to fall asleep and some lost appetite until significantly lost weight while some gain more appetite than usual that significantly become obese. Other common complains are constant fatigue, psychosomatic pain, loss of interest in normally enjoyed activities, easily distracted, influencing decision making processes, or desire to commit suicide. Personally, they also over-criticize themselves as being worthless, hopeless, unlucky and/or unloved. Some may involve with addiction of alcohol or substance abuse. Anyhow, one should get properly diagnosed by a specialist and avoid self-diagnose at any cost as that may do more harm than healing. ${ }^{42}$

${ }^{40}$ Maxime Taquet et al., "Bidirectional Associations between COVID-19 and Psychiatric Disorder: Retrospective Cohort Studies of 62354 COVID-19 Cases in the USA," The Lancet Psychiatry 8, no. 2 (February 2021), accessed January 26, 2021, https://www.thelancet.com/action/showPdf?pii=S22150366\%2820\%2930462-4; Yuval Palgi et al., “The Loneliness Pandemic: Loneliness and Other Concomitants of Depression, Anxiety and Their Comorbidity during the COVID-19 Outbreak," Journal of Affective Disorders 275 (October 2020): 109111, https://linkinghub.elsevier.com/retrieve/pii/S0165032720323946; Dein, "Religious Healing and Mental Health"; Louisa Lorenz, Anne Doherty, and Patricia Casey, "The Role of Religion in Buffering the Impact of Stressful Life Events on Depressive Symptoms in Patients with Depressive Episodes or Adjustment Disorder," International Journal of Environmental Research and Public Health 16, no. 7 (April 8, 2019): 1238, https://www.mdpi.com/1660-4601/16/7/1238.

${ }^{41}$ Beyond Blue, "Depression vs Sadness," Beyond Blue, last modified 2019, accessed December 20, 2020, https://www.beyondblue.org.au/personalbest/pillar/in-focus/depression-vs-sadness.

42 Judith S Beck and Francine Broder, Coping with Depression (New Jersey, USA, 2020), accessed November 11, 2020, https://beckinstitute.org/wpcontent/uploads/2020/09/Coping-with-Depression.pdf. 
Generally, in a psychotherapy, rapport is established between the therapist and the client in the beginning. The client is briefed about what they are going to do and introduced to any CBT methods of choice that is being agreed by both parties, since nowadays there are many new creative therapeutic methods of third wave were invented. ${ }^{43}$

After they are comfortable then they will discuss about the client's problem to give ideas to the therapist to investigate the client's own recurring thought patterns especially related to the tough times in order to detect 'cognitive distortions' in his/her flow of automatic thoughts. Perhaps they derived from misinterpretation or misconception of a belief or information strongly accepted by and deep-rooted in the mind. That is why it needs several chunked sessions and homework to pinpoint the cognitive problem that apparently client is suffering from. Then, the therapist can initiate the healing process by replacing the distorted perceptions until the client realized about the main problem to make sense of his/her depressed feelings and emotions. ${ }^{44}$

The homework usually takes a form of an assignment for the client to examine his/her automatic thoughts: i.e., a brief stream of thought about ourselves and others over a life event. Sometimes, emotions are based on inaccurate ideas termed as "distorted cognitions or dysfunctional beliefs", which we unexpectedly, most of the times than not, believed as real and true. When those ideas formed "intermediate beliefs", they influence attitudes or

${ }^{43}$ Hayes and Hofmann, "The Third Wave of Cognitive Behavioral Therapy and the Rise of Process-Based Care."

44 Beck Institute, "What Is Cognitive Behavior Therapy (CBT)? ," Beck Institute, last modified 2020, accessed November 12, 2020, https://beckinstitute.org/get-informed/what-is-cognitive-therapy/; J.A. Cully and A.L. Teten, A Therapist's Guide to Brief Cognitive Behavioral Therapy, Department of Veterans Affairs South Central MIRECC, 1st ed. (Houston, USA: Department of Veterans Affairs, South Central Mental Illness Research, Education, and Clinical Center (MIRECC), 2008), accessed November 7, 2020, https://depts.washington.edu/dbpeds/therapists_guide_to_brief_cbtmanual.pdf; Neil A Rector, Cognitive-Behavioural Therapy: An Information Guide (Canada: Centre for Addiction and Mental Health, 2010), accessed August 11, 2020, https://www.camh.ca/-/media/files/guides-and-publications/cbt-guide-en.pdf. 
tendencies that usually sound like ultimatums one (if-so) is tied to in deciding about one's life e.g., "if I talk, nobody will listen" but left unchallenged. So, will avoid being expressive and keep suppressing opinions, feelings and emotions from being voiced out. ${ }^{45}$

Islamically, Muslims are educated to refer to revealed sources for the construction of the reality meaning in life, ${ }^{46}$ including for healing since the Qur'an is meant for healing: "We send down the Quran as a healing and mercy for the believers (QS. 17: 82)".

But so far, the researcher did not find any psycho-educational content supplement produced from Qur'anic Thematic Exegetical Analysis (QTEA) on sadness. Albeit the Qur'an is ready to educate Muslims about sadness as it is an undesirable enigmatic emotion that most people found problematic while experiencing it.

Supposed we as Muslims are already matured in this business since it is one of the two first emotions mentioned by Allah before He ordained Prophet Adam to descend to the Earth: "We said, "Descend all of you! Whoever follows My Guidance, they will have no worry, nor will they be continuously sad." (QS. 2: 38).

But we are seemingly influenced by the non-Islamic prescriptions more than appreciating, investigating, and benefitting from Islamic divine legacy. In a book entitled "The Loss of Sadness: How Psychiatry Transformed Normal Sorrow into Depressive Disorder", it shows how they lost it to the psychiatric practice being confused between the normal sadness and the pathological ones, which shared symptoms at feeling sad. ${ }^{47}$

${ }^{45}$ Judith S. Beck, Cognitive Behavior Therapy: Basics and Beyond, 2nd ed. (New York: The Guilford Press, 2011).

${ }^{46}$ Badri, Contemplation: An Islamic Psychospiritual Study ; Ashiq Ali Shah, "Psychotherapy in Vacuum or Reality: Secular or Islamic Psychotherapy with Muslim Clients," Pakistan Journal of Social and Clinical Psychology 3, no. 1-2 (2005).

47 A.V. Horwitz and J.C. Wakefield, The Loss of Sadness: How Psychiatry Transformed Normal Sorrow into Depressive Disorder (New York, USA: Oxford University Press, 2007); Andreea L. Seritan, "The Loss of Sadness: How Psychiatry Transformed Normal Sorrow Into Depressive Disorder" by Allan V. Horwitz and Jerome C. Wakefield. New York, Oxford University Press, 2007, 312 Pp., American Journal of Psychiatry 164, no. 11 (November 2007): 1764-1765, http://psychiatryonline.org/doi/abs/10.1176/appi.ajp.2007.07081263. 
So, let us to investigate in the Qur'an why sadness is important that it is mentioned in the Qur'anic verse, to understand better its function in our life. Then we can integrate the understanding into Islamically adapted psycho-educational psychotherapy (CBT-I) to instill Islamic beliefs and values about sadness, perhaps the understanding will protect our mental hygiene and fortify our resilience in the face of trials and tribulations of life as Rathod found it significantly more effective for religious Muslim clients. ${ }^{48}$

Muslims belong to a dissimilar belief system about human's history from before the story of our creation, to being created, was living in the Heaven before descending on the Earth, and other reality based on the revelation in the Holy Qur'an. In the Islamic belief system, everything is principally unified at the Oneness and Uniqueness (al-Tawhìd) of Allah.

Therefore, Muslims' psyches and selves need different reference and manual to fix it when it is broke down, as it works on different self-concept with dissimilar standards on the perception and ethics of human existence, relationships, and functions compared to the Western mainstream..$^{49}$ We specifically select to work applying the classical method of Qur'anic Thematic Exegetical Analysis (al-Tafsìr al-Mawduci), which is suitable in dealing with the revered holy texts of the Qur'an than the literary critical analysis commonly used by the other scholars in studying the Qur'an.

\section{The Qur'anic Thematic Exegetical Analysis (al-Tafsir al- Mawduci)}

In fact, there are endless aspects of Islam that need to be catered in integrating Islam into the psychotherapy for Muslims. Here, we attempt to contribute by preparing a basic Qur'anic culturally adapted psychoeducation (CaPE concept like in

48 Shanaya Rathod, "Contemporary Psychotherapy and Cultural Adaptations," Journal of Contemporary Psychotherapy 47, no. 2 (June 26, 2017).

49 Shah, "Psychotherapy in Vacuum or Reality: Secular or Islamic Psychotherapy with Muslim Clients." 
Husain's work ${ }^{50}$ ) on sadness by using it as a keyword in searching throughout the Qur'anic.

Literally, sadness in Arabic language is rooted at the past tense verb of feeling sad: ha-za-na (حز), which nouns are: al-hazan and alhuzn. Al-hazan plainly means roughness on the earth surface. Metaphorically, it relates the roughness due to the soul (psyche) experiences pressures and stresses of life, which strip its delightfulness and happiness.

In its noun form of (al-huzn) it means a state of being gloomy, glum, sad, unhappy, distress or that causes suffering/grief or feeling saddened, dejected, depressed, discouraged, dispirited, broken-hearted, upset, sorrow, heartache, sorrowful, mournful, doleful, miserable. Its thesaurus includes melancholy, blues, dolefulness, woefulness, worry, boredom, despondence, trouble, affliction, anguish, doldrums, grim, frowning, pain, scowling, suffering, sullenness, lament, regret, forlorn, and frustration. ${ }^{51}$

Interestingly, Ibnu al-Qayyim al-Jawzi explained that something is saddening due to the attachment to the love feeling to it i.e., a loss of family member you loved will sadden you but not just any loss of somebody you did not even know. Also, he observed that the worry is induced by an expectation of mishap that will happen. When it happened, then, it is replaced by the sadness. While in the pathological sense in the spectrum is the interesting relationship between anxiety and depression. ${ }^{52}$

We add 'cry' and 'tears' as keywords also to enrich and broaden the coverage (al-isticāb) the search. Similar to the thematic

${ }^{50}$ Muhammad Ishrat Husain et al., "Pilot Study of a Culturally Adapted Psychoeducation (CaPE) Intervention for Bipolar Disorder in Pakistan," Int J Bipolar Disord 5 (2017): 3, accessed October 19, 2020, http://www.randomisation.com.

${ }^{51}$ Almaany, "Translation and Meaning of Almaani in English - Arabic Terms Dictionary," last modified 2019, https://www.almaany.com/en/dict/ar-en/almaani/.

52 Muhammad ibn 'Abī Bakr ibn Ayyūb al-Zurcī al-Dimashqī al-Ḥanbalī (1292-1350CE/691-751AH) Ibnu al-Qayyim Al-Jawzi, Shams al-Dīn, Abū 'Abd Allah, Rauḍh Al-Muhibbīn Wa Nuzhat Al-Mushtāqinn (Trans. My. Taman OrangOrang Yang Mencintai Dan Memendam Rindu/En. Love and Missing Feelings in the Qur'an and Sunnah)., ed. Tr. Kathur Suhardi, 2nd ed. (Jakarta, Indonesia: Darul Falah, 1997). 
analysis in its essence, the collected raw data of the Qur'anic verses was coded accordingly and themed up with due respect to the Qur'anic sciences principles, especially the exegesis of the Qur'an. ${ }^{53}$

Briefly, the Qur'anic verses are best interpreted by other verses and then by the Prophetic Tradition (Hadith/Sunnah). ${ }^{54}$ The English translation for the selected Qur'anic verses is from the Clear Qur'an by Dr. Mustafa Khattab. ${ }^{55}$ Some interpretations are being clarified primarily by referring to the Al-Qurtubī's Qur'anic Exegesis (Tafsìr al-Qurtubī) extracted from the list of exegeses in the Qur'an Android app. ${ }^{56}$ The reading is double checked with the book version of the exegesis. ${ }^{57}$ The codes are transformed into apparent themes and then, the emergent themes for easier explanation as a concept.

The usage of al-Qurtubi's exegesis and explaining from the Sunni view are among limitations of this study. Since, the

${ }^{53}$ Muhsin Hāmid Al-Muțairī, Tafsīr Al-Qur'ān Bil Qur'ān: Ta'șìl Wa Taqwīm [Trans. Qur'anic Exegesis with the Qur'an: Origin and Correction ] (Riyadh, KSA: Dārul Tadamuriyyah, 2011); Musțafā Muslim, Mabāhits Fi Al-Tafsīr Al-Mawḍūci [Tr. Researches in Exegetical Thematic Analysis Methodology] (Damascus, Syria: Darul Qalam, 1989); Sohaib Saeed, "Thematic Tafsir Methodology," Quranica, last modified 2012, accessed December 23, 2020, http://quranica.com/thematic-tafsirmethodology/; Fadzli Adam and Asyraf Ab Rahman, Tafsīr and Mufassirūn: An Overview (Kuala Lumpur, Malaysia: A.S. Noordeen, 2003); Mohamed El-Tahir ElMesawi, "Review - The Holy Qur'an Method of Qur'anic Thematic Exegetical Analysis: Critical Analysis (Ar. Murāja'ah - Manhaj Al-Tafsīr Al-Mauḍu'ī Li AlQur'ān Al-Karīm: Dirāsah Naqdiyyah)," At-Tajdid 15, no. 29 (2011): 231-242, https://journals.iium.edu.my/at-tajdid/index.php/tajdid/article/view/134/110;

Murad Al-Shawabkah, "Al-Tafsīr Al-Maudu'ī (Trans. Qur'anic Thematic Exegetical Analysis)," Mawdoo3, last modified June 16, 2020, accessed March 18, 2021, https://mawdoo3.com/التفسير_الموضوعي.

${ }^{54}$ Al-Muțairī, Tafsīr Al-Qur'ān Bil Qur'ān: Ta'șìl Wa Taqwīm [Trans. Qur'anic Exegesis with the Qur'an: Origin and Correction ].

${ }^{55}$ Mustafa Khattab, "The Clear Qur'an," Quran for Android.

${ }^{56}$ Ahmed El-Helw et al., "Quran for Android App" (quran.com, December 31, 2017).

57 Abū 'Abdullah, Muhammad ibn Ahmad ibn Abū Bakr al-Ansāri alKhazraj̄̄ Shams al-Dīn al-Qurtubī, Al-Qurtubi's Exegesis: Al-Jāmic Li Ahkām AlQur'ān (Tr. The Compendium of Jurisprudential Rulings of the Qur'an), 2nd ed., vol. 10 (Cairo: Darul al-Kotob al-Misriyyah, 1964), accessed January 26, 2021, https://al-maktaba.org/book/31702. 
researchers are Sunni Muslim, so, they are more familiar with this ideological view.

The anticipated hope is that the Sunni Muslim clients can work together with their psychotherapists to compare what they thought about things that sadden them or the sadness itself whether it is pathological or normal according to Islamic orientation in preventing or treating depression as accurate belief system is promised to not experience worry nor to be sad for long until became pathologically depressed.

However, it is worth noting that there are cases of depression that has no relation with cognitive reasons like having brain tumor, secondary illness from another primary chronic illness like heart problems, hypothyroidism, seasonal due to lack of sunlight, lack of Vitamin D, etc.. 58

Tables 1-3 list the Qur'anic verses related to sadness (for replication with other exegeses (tafāsīr)).

Table 1. List of the Qur'anic verses related to sadness from derivatives of past tense for sadness ( $h a-z a-n a-2) .{ }^{59}$

\begin{tabular}{|c|c|c|l|}
\hline No. & Chapter & $\begin{array}{c}\text { Verse } \\
\text { (Ayah) }\end{array}$ & $\begin{array}{l}\text { English Translation from The Clear Qur'an by } \\
\text { Dr. Mustafa Khattab }\end{array}$ \\
\hline & 38 & $\begin{array}{l}\text { We said, "Descend all of you! Then when } \\
\text { guidance comes to you from Me, whoever } \\
\text { follows it, there will be no worry for them, nor } \\
\text { they will always be sad. }\end{array}$ \\
\cline { 3 - 4 } & $\begin{array}{c}\text { Chapter 2 } \\
\text { Sürah Al- } \\
\text { Baqarah } \\
\text { (Chapter } \\
\text { The Cow) }\end{array}$ & 62 & $\begin{array}{l}\text { Indeed, the believers, Jews, Christians, and } \\
\text { Sabians - whoever truly' believes in Allah and } \\
\text { the Last Day and does good deeds will have } \\
\text { their reward with their Lord. And there will be } \\
\text { no worry for them, nor they will always be sad. }\end{array}$ \\
\cline { 3 - 4 } & 112 & $\begin{array}{l}\text { But no! Whoever submits themselves to Allah } \\
\text { and does good deeds will have their reward }\end{array}$ \\
\hline
\end{tabular}

${ }^{58}$ Mary Jane England and Leslie J. Sim, “The Etiology of Depression," in Depression in Parents, Parenting, and Children: Opportunities to Improve Identification, Treatment, and Prevention (US National Academies Press , 2009), 1-488, accessed April 5, 2021, https://www.ncbi.nlm.nih.gov/books/NBK215119/.

59 with alteration appropriately suits this work e.g. for coding - the list is provided for replication with other exegesis and English translation of the Holy Qur'an. It is absent of example of coding and theme-ing due to limitation of word count. 


\begin{tabular}{|c|c|c|c|}
\hline No. & Chapter & $\begin{array}{c}\text { Verse } \\
\text { (Ayah) }\end{array}$ & $\begin{array}{l}\text { English Translation from The Clear Qur'an by } \\
\text { Dr. Mustafa Khattab }\end{array}$ \\
\hline & & & $\begin{array}{l}\text { with their Lord. And there will be no worry for } \\
\text { them, nor they will always be sad. }\end{array}$ \\
\hline & & 262 & $\begin{array}{l}\text { Those who spend their wealth in the cause of } \\
\text { Allah and do not follow their charity with } \\
\text { reminders of their generosity or hurtful words - } \\
\text { they will get their reward from their Lord, and } \\
\text { there will be no worry for them, nor they will } \\
\text { always be sad. }\end{array}$ \\
\hline & & 274 & $\begin{array}{l}\text { Those who spend their wealth in charity day } \\
\text { and night, secretly and openly - their reward is } \\
\text { with their Lord, and there will be no worry for } \\
\text { them, nor they will always be sad. }\end{array}$ \\
\hline & & 277 & $\begin{array}{l}\text { Indeed, those who believe, do good deeds, } \\
\text { establish prayer, and pay alms-tax will receive } \\
\text { their reward from their Lord, and there will be } \\
\text { no worry for them, nor they will always be sad. }\end{array}$ \\
\hline \multirow{4}{*}{2} & \multirow{4}{*}{$\begin{array}{l}\text { Chapter } 3 \\
\text { Sürah } \bar{A} l \\
\text { 'Imrānn } \\
\text { (Chapter } \\
\text { The Family } \\
\text { of Imran) }\end{array}$} & 139 & $\begin{array}{l}\text { Do not falter or be sad, for you will have the } \\
\text { upper hand if you are 'true' believers. }\end{array}$ \\
\hline & & 153 & $\begin{array}{l}\text { 'Remember' when you were running far away } \\
\text { 'in panic' - not looking at anyone - while the } \\
\text { Messenger was calling to you from behind! So, } \\
\text { Allah rewarded your disobedience with distress } \\
\text { upon distress. Now, do not be sad over the } \\
\text { victory you were denied or the injury you } \\
\text { suffered. And Allah is All-Aware of what you } \\
\text { do. }\end{array}$ \\
\hline & & 170 & $\begin{array}{l}\text { rejoicing in Allah's bounties and being delighted } \\
\text { for those yet to join them. There will be no worry } \\
\text { for them, nor they will always be sad. }\end{array}$ \\
\hline & & 176 & $\begin{array}{l}\text { 'O Prophet!' Do not be sad for those who race to } \\
\text { disbelieve - surely they will not harm Allah in } \\
\text { the least. It is Allah's Will to disallow them a } \\
\text { share in the Hereafter, and they will suffer a } \\
\text { tremendous punishment. }\end{array}$ \\
\hline 3 & $\begin{array}{l}\text { Chapter } 5 \\
\text { Sürah al-Mā- } \\
\text { idah } \\
\text { (Chapter } \\
\text { The } \\
\text { Banquet) }\end{array}$ & 41 & $\begin{array}{l}\text { O Messenger! Do not be sad for those who } \\
\text { hastily disbelieve - those who say, "We believe" } \\
\text { with their tongues, but their hearts are in } \\
\text { disbelief. Nor those among the Jews who eagerly } \\
\text { listen to lies, attentive to those who are too } \\
\text { arrogant to come to you. They distort the } \\
\text { Scripture, taking rulings out of context, then say, } \\
\text { "If this is the ruling you get 'from Muhammad", } \\
\text { accept it. If not, beware!" Whoever Allah allows } \\
\text { to be deluded, you can never be of any help to }\end{array}$ \\
\hline
\end{tabular}




\begin{tabular}{|c|c|c|c|}
\hline No. & Chapter & $\begin{array}{l}\text { Verse } \\
\text { (Ayah) }\end{array}$ & $\begin{array}{l}\text { English Translation from The Clear Qur'an by } \\
\text { Dr. Mustafa Khattab }\end{array}$ \\
\hline & & & $\begin{array}{l}\text { them against Allah. It is not Allah's Will to } \\
\text { purify their hearts. They will suffer disgrace in } \\
\text { this world and a tremendous punishment in the } \\
\text { Hereafter. }\end{array}$ \\
\hline & & 69 & $\begin{array}{l}\text { Indeed, the believers, Jews, Sabians and } \\
\text { Christians-whoever 'truly' believes in Allah } \\
\text { and the Last Day and does good deeds, there } \\
\text { will be no worry for them, nor they will always } \\
\text { be sad. }\end{array}$ \\
\hline \multirow{2}{*}{4} & \multirow{2}{*}{$\begin{array}{l}\text { Chapter } 6 \\
\text { Sūrah al- } \\
\text { Ancam } \\
\text { (Chapter } \\
\text { The } \\
\text { Poultry) }\end{array}$} & 33 & $\begin{array}{l}\text { We certainly know that what they said saddens } \\
\text { you 'O Prophet'. It is not your honesty they } \\
\text { question - it is Allah's signs that the wrongdoers } \\
\text { deny. }\end{array}$ \\
\hline & & 48 & $\begin{array}{l}\text { We have sent messengers only as deliverers of } \\
\text { good news and as warners. Whoever believes } \\
\text { and does good deeds, there will be no worry for } \\
\text { them, nor they will always be sad. }\end{array}$ \\
\hline \multirow{2}{*}{5} & \multirow{2}{*}{$\begin{array}{c}\text { Chapter } 7 \\
\text { Sūrah Al- } \\
A^{c} r a \bar{f} \\
\text { (Chapter } \\
\text { The } \\
\text { Elevations) }\end{array}$} & 35 & $\begin{array}{l}\text { O'children of Adam! When messengers from } \\
\text { among yourselves come to you reciting My } \\
\text { revelations - whoever shuns evil and mends } \\
\text { their ways, there will be no worry for them, nor } \\
\text { they will always be sad. }\end{array}$ \\
\hline & & 49 & $\begin{array}{l}\text { Are these 'humble believers" the ones you swore } \\
\text { would never be shown Allah's mercy?" 'Finally, } \\
\text { those on the heights will be told: " "Enter } \\
\text { Paradise! You will have nothing to worry, nor } \\
\text { will you be sad." }\end{array}$ \\
\hline \multirow[t]{2}{*}{6} & \multirow[t]{2}{*}{$\begin{array}{c}\text { Chapter } 9 \\
\text { Sūrah Al- } \\
\text { Tawbah } \\
\text { (Chapter } \\
\text { The } \\
\text { Repentance) }\end{array}$} & 40 & $\begin{array}{l}\text { 'It does not matter' if you 'o'believers" do not } \\
\text { support him, for Allah did in fact support him } \\
\text { when the disbelievers drove him out 'of Mecca' } \\
\text { and he was only one of two. While they both } \\
\text { were in the cave, he reassured his companion, } \\
\text { "Do not be sad, for Allah is undoubtedly with } \\
\text { us." So, Allah sent down His serenity upon the } \\
\text { Prophet, supported him with forces you } \\
\text { 'believers" did not see, and made the word of the } \\
\text { disbelievers lowest, while the Word of Allah is } \\
\text { supreme. And Allah is Almighty, All-Wise. }\end{array}$ \\
\hline & & 92 & $\begin{array}{l}\text { Nor 'is there any blame on" those who came to } \\
\text { you 'O'Prophet" for mounts, then when you } \\
\text { said, "I can find no mounts for you," they left } \\
\text { with eyes overflowing with tears out of sorrow } \\
\text { that they had nothing to contribute. }\end{array}$ \\
\hline 7 & Chapter 10 & 62 & There will certainly be no worry for the close \\
\hline
\end{tabular}




\begin{tabular}{|c|c|c|c|}
\hline No. & Chapter & $\begin{array}{l}\text { Verse } \\
\text { (Ayah) }\end{array}$ & $\begin{array}{l}\text { English Translation from The Clear Qur'an by } \\
\text { Dr. Mustafa Khattab }\end{array}$ \\
\hline & \multirow{2}{*}{$\begin{array}{l}\text { Sürah Yūnus } \\
\text { (Chapter } \\
\text { Jonas) }\end{array}$} & & $\begin{array}{l}\text { servants of Allah, nor will they continuously be } \\
\text { sad. }\end{array}$ \\
\hline & & 65 & $\begin{array}{l}\text { Do not let their words sadden you 'O Prophet'. } \\
\text { Surely all honor and power belong to Allah. He } \\
\text { is the All-Hearing, All-Knowing. }\end{array}$ \\
\hline \multirow{3}{*}{8} & \multirow{3}{*}{$\begin{array}{l}\text { Chapter } 12 \\
\text { Sūrah Yüsuf } \\
\text { (Chapter } \\
\text { Joseph) }\end{array}$} & 13 & $\begin{array}{l}\text { He responded, "It would truly sadden me if you } \\
\text { took him away with you, and I fear that a wolf } \\
\text { may devour him while you are negligent of } \\
\text { him." }\end{array}$ \\
\hline & & 84 & $\begin{array}{l}\text { He turned away from them, lamenting, "Alas, } \\
\text { poor Joseph!" And his eyes turned white out of } \\
\text { the bereavement he suppressed. }\end{array}$ \\
\hline & & 86 & $\begin{array}{l}\text { He replied, "I complain of my anguish and } \\
\text { sorrow only to Allah, and I know from Allah } \\
\text { what you do not know. }\end{array}$ \\
\hline 9 & $\begin{array}{c}\text { Chapter } 15 \\
\text { Sūrah al-Hijr } \\
\text { (Chapter } \\
\text { The Rocky } \\
\text { Cities of } \\
\text { Thamud) }\end{array}$ & 88 & $\begin{array}{l}\text { Do not let your eyes crave the 'fleeting' } \\
\text { pleasures We have provided for some of the } \\
\text { disbelievers, do not grieve over them. And be } \\
\text { gracious to the believers. }\end{array}$ \\
\hline 10 & $\begin{array}{l}\text { Chapter } \mathbf{1 6} \\
\text { Sürah al- } \\
\text { Nahl } \\
\text { (Chapter } \\
\text { The Bee) }\end{array}$ & 127 & $\begin{array}{l}\text { Be patient 'O'Prophet', for your patience is only } \\
\text { with Allah's help. Do not be sad over those 'who } \\
\text { disbelieve', nor be distressed by their schemes. }\end{array}$ \\
\hline 11 & $\begin{array}{l}\text { Chapter } 19 \\
\text { Sūrah } \\
\text { Maryam } \\
\text { (Chapter } \\
\text { Mary) } \\
\end{array}$ & 24 & $\begin{array}{l}\text { So, a voice reassured her from below her, "Do } \\
\text { not be sad! Your Lord has provided a stream at } \\
\text { your feet. }\end{array}$ \\
\hline 12 & $\begin{array}{l}\text { Chapter } 20 \\
\text { Sūrah Tā-Hā } \\
\text { (Chapter } \\
\text { Tā-Hā) }\end{array}$ & 40 & $\begin{array}{l}\text { 'Remember' when your sister came along and } \\
\text { proposed, 'Shall I direct you to someone who } \\
\text { will nurse him?' So We reunited you with your } \\
\text { mother so that her heart would be put at ease, } \\
\text { and she would not be sad. 'Later' you killed a } \\
\text { man 'by mistake', but We saved you from } \\
\text { sorrow, as well as other tests We put you } \\
\text { through. Then you stayed for a number of years } \\
\text { among the people of Midian. Then you came } \\
\text { here as pre-destined, O'Moses! }\end{array}$ \\
\hline
\end{tabular}




\begin{tabular}{|c|c|c|c|}
\hline No. & Chapter & $\begin{array}{l}\text { Verse } \\
\text { (Ayah) }\end{array}$ & $\begin{array}{l}\text { English Translation from The Clear Qur'an by } \\
\text { Dr. Mustafa Khattab }\end{array}$ \\
\hline 13 & $\begin{array}{l}\text { Chapter } 21 \\
\text { Sūrah al- } \\
\text { Anbiy } \bar{a}^{\prime} \\
\text { (Chapter } \\
\text { The } \\
\text { Prophets) }\end{array}$ & 103 & $\begin{array}{l}\text { The Supreme Horror 'of that Day" will not } \\
\text { sadden them, and the angels will greet them, } \\
\text { 'saying," "This is your Day, which you have } \\
\text { been promised." }\end{array}$ \\
\hline 14 & $\begin{array}{l}\text { Chapter } 27 \\
\text { Sürah al- } \\
\text { Naml } \\
\text { (Chapter } \\
\text { The Ant) }\end{array}$ & 70 & $\begin{array}{l}\text { Do not be sad for them, nor be distressed by } \\
\text { their schemes. }\end{array}$ \\
\hline \multirow{3}{*}{15} & \multirow{3}{*}{$\begin{array}{l}\text { Chapter } 28 \\
\text { Sürah al- } \\
\text { Qașaș } \\
\text { (Chapter } \\
\text { Narrations) }\end{array}$} & 7 & $\begin{array}{l}\text { We inspired the mother of Moses: "Nurse him, } \\
\text { but when you worried about him, put him then } \\
\text { into the river, and do not worry or be sad. We } \\
\text { will certainly return him to you, and make him } \\
\text { one of the messengers." }\end{array}$ \\
\hline & & 8 & $\begin{array}{l}\text { And it so happened that' Pharaoh's people } \\
\text { picked him up, only to become their enemy and } \\
\text { source of sorrow. Surely Pharaoh, Hamān, and } \\
\text { their soldiers were sinful. }\end{array}$ \\
\hline & & 13 & $\begin{array}{l}\text { This is how We returned him to his mother, so } \\
\text { that her heart would be put at ease, and not sad, } \\
\text { and that she would know that Allah's promise is } \\
\text { 'always' true. But most people do not know. }\end{array}$ \\
\hline 16 & $\begin{array}{c}\text { Chapter } 29 \\
\text { Sürah Al- } \\
\text { Ankabüt } \\
\text { (Chapter } \\
\text { The Spider) }\end{array}$ & 33 & $\begin{array}{l}\text { And when Our messenger-angels came to Lot, } \\
\text { he was distressed and worried by their arrival. } \\
\text { They reassured 'him", "Do not worry, nor be } \\
\text { sad. We will surely deliver you and your } \\
\text { family-except your wife, who is one of the } \\
\text { doomed. }\end{array}$ \\
\hline 17 & $\begin{array}{l}\text { Chapter } 31 \\
\text { Sūrah } \\
\text { Luqmān } \\
\text { (Chapter } \\
\text { Lukman) }\end{array}$ & 23 & $\begin{array}{l}\text { But whoever disbelieves, do not let their } \\
\text { disbelief saddens you 'O Prophet'. To Us is their } \\
\text { return, and We will inform them of all they did. } \\
\text { Surely Allah knows best what is 'hidden' in the } \\
\text { heart. }\end{array}$ \\
\hline 18 & $\begin{array}{l}\text { Chapter } 33 \\
\text { Sürah Al- } \\
\text { Ahzāb } \\
\text { (Chapter } \\
\text { The } \\
\text { Coalition) }\end{array}$ & 51 & $\begin{array}{l}\text { It is up to you 'O'Prophet' to delay/hasten the } \\
\text { turn whoever you please among your wives. } \\
\text { There is no problem to put the turn to anyone } \\
\text { who was delayed after that as that will entertain } \\
\text { them, to prevent them from feeling sad, and all } \\
\text { will feel very pleased with what you offered to } \\
\text { each of them. Allah 'fully' knows what is in the } \\
\text { hearts of all of you. And Allah is All-Knowing, } \\
\text { Most Forbearing. }\end{array}$ \\
\hline
\end{tabular}




\begin{tabular}{|c|c|c|c|}
\hline No. & Chapter & $\begin{array}{l}\text { Verse } \\
\text { (Ayah) }\end{array}$ & $\begin{array}{l}\text { English Translation from The Clear Qur'an by } \\
\text { Dr. Mustafa Khattab }\end{array}$ \\
\hline \multirow[t]{2}{*}{19} & $\begin{array}{l}\text { Chapter } 35 \\
\text { Sürah Fätir } \\
\text { (Chapter } \\
\text { The } \\
\text { Originator }\end{array}$ & 34 & $\begin{array}{l}\text { And they will say, "Praise be to Allah, Who has } \\
\text { kept away from us all 'causes of" sadness (in the } \\
\text { heaven). Our Lord is indeed All-Forgiving, Most } \\
\text { Appreciative. }\end{array}$ \\
\hline & $\begin{array}{l}\text { Chapter } 36 \\
\text { Sūrah Yāsin } \\
\text { (Chapter } \\
\text { Yāsin) } \\
\end{array}$ & 76 & $\begin{array}{l}\text { So do not let their words sadden you 'O } \\
\text { Prophet'. Indeed, We 'fully' know what they } \\
\text { conceal and what they reveal. }\end{array}$ \\
\hline 20 & $\begin{array}{l}\text { Chapter } 39 \\
\text { Sūrah Al- } \\
\text { Zumar } \\
\text { (Chapter } \\
\text { The Troops) }\end{array}$ & 61 & $\begin{array}{l}\text { And Allah will deliver those who were mindful } \\
\text { 'of Him' to their place of 'ultimate' triumph. No } \\
\text { bad thing will touch them, nor will they be sad. }\end{array}$ \\
\hline 21 & $\begin{array}{l}\text { Chapter } 41 \\
\text { Sūrah Al- } \\
\text { Fușșilāt } \\
\text { (The } \\
\text { Details) }\end{array}$ & 30 & $\begin{array}{l}\text { Surely those who say, "Our Lord is Allah," and } \\
\text { then remain steadfast, the angels descend upon } \\
\text { them, 'saying," "Do not worry, nor be sad. } \\
\text { Rather, rejoice in the good news of Paradise, } \\
\text { which you have been promised. }\end{array}$ \\
\hline 22 & $\begin{array}{c}\text { Chapter } 43 \\
\text { Sūrah Al- } \\
\text { Zukhruf } \\
\text { (Chapter } \\
\text { The } \\
\text { Ornament } \\
\text { of Gold) }\end{array}$ & 68 & $\begin{array}{l}\text { 'who will be told,' “O'My servants! There is no } \\
\text { worry for you Today (the Judgement Day), nor } \\
\text { will you be sad - }\end{array}$ \\
\hline 23 & $\begin{array}{l}\text { Chapter } 46 \\
\text { Sūrah Al- } \\
\text { Ahquāf (The } \\
\text { Sand } \\
\text { Dunes) }\end{array}$ & 13 & $\begin{array}{l}\text { Surely those who say, "Our Lord is Allah," and } \\
\text { then remain steadfast - there will be no worry } \\
\text { for them, nor will they always be sad. }\end{array}$ \\
\hline 24 & $\begin{array}{c}\text { Chapter } 58 \\
\text { Sūrah Al- } \\
\text { Mujādalah } \\
\text { (Chapter } \\
\text { The } \\
\text { Argument) }\end{array}$ & 10 & $\begin{array}{l}\text { Secret talks are only inspired by Satan to sadden } \\
\text { the believers. Yet he cannot harm them } \\
\text { whatsoever except by Allah's Will. So, in Allah } \\
\text { let the believers put their trust. }\end{array}$ \\
\hline
\end{tabular}

Table 2. List of the Qur'anic verses related to sadness from the derivatives of tear (da-ma-a - دمع)

\begin{tabular}{|c|c|c|l|}
\hline No. & Chapter & $\begin{array}{c}\text { Verse } \\
\text { (Ayah) }\end{array}$ & $\begin{array}{l}\text { English Translation from The Clear Qur'an } \\
\text { by Dr. Mustafa Khattab }\end{array}$ \\
\hline 1 & Chapter 5 & 83 & When they listen to what has been revealed to \\
\hline
\end{tabular}




\begin{tabular}{|c|c|c|l|}
\hline No. & Chapter & $\begin{array}{c}\text { Verse } \\
\text { (Ayah) }\end{array}$ & $\begin{array}{l}\text { English Translation from The Clear Qur'an } \\
\text { by Dr. Mustafa Khattab }\end{array}$ \\
\hline $\begin{array}{c}\text { Sürah Al-Ma- } \\
\text { 'idah } \\
\text { (Chapter The } \\
\text { Banquet) }\end{array}$ & $\begin{array}{l}\text { Chapter 9 } \\
\text { the Messenger, you see their eyes overflowing } \\
\text { with tears for recognizing the truth. They say, } \\
\text { "Our Lord! We believe, so count us among the } \\
\text { witnesses. }\end{array}$ \\
\hline $\begin{array}{c}\text { Tawbah } \\
\text { (Chapter The } \\
\text { Repentance) }\end{array}$ & 92 & $\begin{array}{l}\text { Nor 'is there any blame on' those who came to } \\
\text { you 'O'Prophet' for mounts, then when you } \\
\text { said, "I can find no mounts for you," they left } \\
\text { with eyes overflowing with tears out of } \\
\text { sorrow that they had nothing to contribute. }\end{array}$ \\
\hline
\end{tabular}

Table 3. List of the Qur'anic verses related to sadness from the derivatives of cry (ba-kā - بكى)

\begin{tabular}{|c|c|c|c|}
\hline No. & Chapter & $\begin{array}{l}\text { Verse } \\
\text { (Ayah) }\end{array}$ & $\begin{array}{l}\text { English Translation from The Clear Qur'an } \\
\text { by Dr. Mustafa Khattab }\end{array}$ \\
\hline 1 & $\begin{array}{c}\text { Chapter } 9 \\
\text { Sūrah Al- } \\
\text { Tawbah } \\
\text { (Chapter The } \\
\text { Repentance) }\end{array}$ & 16 & $\begin{array}{l}\text { So, let them laugh a little - they will weep } \\
\text { much as a reward for what they have } \\
\text { committed. }\end{array}$ \\
\hline 2 & $\begin{array}{l}\text { Chapter } 12 \\
\text { Sūrah Yüsuf } \\
\text { (Chapter } \\
\text { Joseph) } \\
\end{array}$ & 16 & $\begin{array}{l}\text { Then they returned to their father in the } \\
\text { evening, weeping. }\end{array}$ \\
\hline 3 & $\begin{array}{c}\text { Chapter } \mathbf{1 7} \\
\text { Sūrah al-Isrä' } \\
\text { (Chapter The } \\
\text { Night } \\
\text { Journey) }\end{array}$ & 109 & $\begin{array}{l}\text { And they fall down upon their faces weeping, } \\
\text { and it increases them in humility." }\end{array}$ \\
\hline \multirow[b]{2}{*}{4} & \multirow{2}{*}{$\begin{array}{l}\text { Chapter } 53 \\
\text { Sūrah Al- } \\
\text { Najm } \\
\text { (Chapter The } \\
\text { Star) }\end{array}$} & 43 & $\begin{array}{l}\text { [Moreover] He is the One who Makes [one] to } \\
\text { laugh (to feel happy) or cry (to feel sad). }\end{array}$ \\
\hline & & $59-60$ & laughing 'at it' and not weeping 'in awe', \\
\hline
\end{tabular}

\section{The Quranic Concept of Sadness}

Albeit Prof. Dr. Malik Babikir Badri, the founder of Islamic Psychology, endorsed the effectiveness of Cognitive Behavior Therapy (CBT), ${ }^{60}$ anyhow we must be very careful in integrating Islam into $\mathrm{CBT}$ on the ground of compatibility to Islamic fundamentals, especially at the Creed level ( ${ }^{c}$ Aqidah).

\footnotetext{
${ }^{60}$ Badri, Contemplation.
} 
There are aspects of CBT, which are of Western epistemological fundamentals that are either based on constructivistic orientation (based on idiosyncratic i.e., individualbased reality) or rationalistic orientation (based on tangible absolute reality), incompatible with Islam $^{61}$ that made it "antithetical to Islam". ${ }^{62}$ We must purify and process our information through the sciences of Foundations of Religion (Ușūl al-dinn) and Foundations of Islamic Jurisprudence (Ușūl al-figh) to adaptively orient accordingly permissible practice from the CBT. Specifically, referring the foundations of exegesis (Ușūl al-Tafsìr) when using the Qur'an and its exegesis like here.

Departing from the above-mentioned important preconditions, we shift to the understanding about sadness as offered by the Qur'an. Sadness is a recognized emotion in Islam and one of the first two emotions mentioned in the Holy Qur'an, before Adam was ordained to descend on the Earth (QS. 2: 38). Sadness is an emotion felt as a reaction when 'something harmful/awful/wrong/bad ( $a l-s \bar{u}$ ': (Q:39: 61)) befell on us as human beings. Before it happens/we frustrate, it appears in the form of worry when we expect or suspect such events will be happening, because they are innately undesired to really happen.

Seemingly, it reflects the distant memory of the psyche (soul) about the better life experience in the heaven (Jannah) before being ordained to descend onto the Earth (QS. 2: 38) as the difficult life events of the earthly existence are non-existent in the Jannah (QS. 35: 34). At here-life (al-Dunyā) level, we can liken it the feelings of somebody who came from somewhere more safer, prosperous and technologically advanced place but have to migrate to somewhere less resourceful with the least technology one used to live easier with it previously, or like from lush land to arid or icy land, which is challenging to survive. Of course, that will induce strong

${ }^{61}$ Beshai, Clark, and Dobson, "Conceptual and Pragmatic Considerations in the Use of Cognitive-Behavioral Therapy with Muslim Clients."

${ }^{62}$ Carrie Y. Al-Karam, Islamically Integrated Psychotherapy: Uniting Faith and Professional Practice. - Alkaram Institute (USA: Templeton Press, 2018), accessed September 2, 2020, https://alkaraminstitute.org/islamically-integratedpsychotherapy-uniting-faith-and-professional-practice/; Sabry and Vohra, "Role of Islam in the Management of Psychiatric Disorders." 
missing feeling and hopeful desire yearning to return to the better place than have to continuously endure sufferings and afflictions in the worse foreign place.

Allah SWT had warned the consequences of feeling fearful and sad, which are as ancient as the duration of human earthly existence (QS. 2: 38) against disobedience towards His Guidance both individually and more collectively. Allah Uses it as a tool to test the love feelings where human beings must love Him and the Prophet Muhammad above everything else as His servants ( $c i b \bar{a} d$ Allah/Al-Rahmān) as the main reason He Created us, to worship Him (liyacbudūni in (QS. 51: 56).

The tests may appear in the form of: (i) fear, (ii) hunger and (iii) loss/lack of wealth or properties, selves or lives, and fruits or food (QS. 2: 155). Hence, when those tests happened, our fearful or sad emotions will play the role of a compass/sensor over measuring our initiatives in obeying His Guidance (QS. 2: 38). Provided, we follow His Guidance, so, nothing that we are fearful of will influence us badly, also, we will not continuously be sad (QS. 2: 38).

Basically, the Qur'an teaches us to say istirjāc: 'Innālillähi wa innā ilayhi rājic $\bar{u} n^{\prime}$ whenever any mishap befalls us, which means: "Indeed we are from Allah and to Him we will return." Whoever said that Allah Promises him/her:

a) His Blessing (șalawāt min rabbihim)

b) His Mercy (rahmah)

c) His Guidance (ihtidā' - guiding instinct with extra bonus of pacifying effects (insyirah) and resiliency (tathbitt) ${ }^{63}$ or ease up the way out from any problem and reducing the feeling of sadness. ${ }^{64}$

The Qur'an also educates us to give the priority on putting efforts to avoid eternal sadness in the matters of the Hereafter ( $\mathrm{Al}$ $\bar{A} k h i r a h)$ than of this life (al-Dunyā) (QS. 53: 58-60). We have to trust Allah (QS. 5: 11) that He is managing everything the best for

${ }^{63} \mathrm{Abū}$ 'Alī, Al-Faḍl bin Al-Hasan Al-Ṭabarsī, Majmā' Al-Bayān F̄̄ Tafsīr AlQur'ān, 1st ed., vol. 8 (Beirut, Lebanon: Dār Al-cUlūm, 2005).

${ }^{64}$ al-Qurtubī, Al-Qurtubi's Exegesis: Al-Jāmic Li Ahkām Al-Qur'ān (Tr. The Compendium of Jurisprudential Rulings of the Qur'an), vol. 10, p. 
us where He affirms that whenever harm touches anyone, nobody could free from it except Him, neither anyone could withhold any bounty that is destined when He had granted so upon His wisdom (QS. 10:107). So, whatever happens in the duration of life, actually, Allah is the One who makes us laugh (happy) and cry (sad) (QS. 53: 43). He had predestined all the matters in details (QS. 3: 154, QS. 65: 3). In the end, we will return to Him (QS. 2: 46, QS. 2:156, QS. 21: 93, QS. 23: 60).

The Holy Qur'an also already guides us about what makes us occasionally feel sad - as we list it below:

\section{Elicitors of Sadness:}

1. Living on the Earth (QS. 2: 38)

2. Prophethood duties (QS. 2: 262-263, QS. 3: 176, QS. 5: 41, QS. 6: 33-35, QS. 36: 76), which may be equivalent to leadership or preaching responsibilities in the non-prophet human beings.

3. Usury (Ribā) (QS. 2: 276-277).

4. Rivalry especially from someone close to you e.g., a family member ${ }^{65}$ or friend (QS. 12: 13; QS. 12: 82-86, QS. 12: 100, QS. 28: 8).

5. When a person is obsessed and fixated on a saddening event and refused to let go but let the mishap of life to weaken and degrade himself (QS. 3: 139 \& 146).

6. When somebody is tried with a series of adversity at the same time (QS. 3: 153).

7. Suspicion towards Allah with lack of trust and assurance to Him in managing his businesses in life (QS. 3: 154; 28: 10).

8. Loss of something like loss of the loved one(s) e.g., child (QS. 12: 8466; QS. 20: 4067; QS. 28: 7).

9. Unfortunate experience(s) (QS. 3: 153).

10. Facing hypocrisy from other people (QS. 3: 154-156).

\footnotetext{
${ }^{65}$ E.g., as Allah Decreed the rivalry of Prophet $M \bar{u} s \bar{a}$ (Moses) a.s. as a cause of sadness to the Pharoah (Fircaun) as his rival/enemy.

${ }^{66}$ The Story of Prophet Jacob $\left(Y a^{c} q \bar{u} b\right)$ a.s. who lost his dearest son: Prophet Joseph (Yüsuf) a.s.

${ }^{67}$ The story of Prophet Moses' (Mūsā) a.s. mother.
} 
11. The evil urging hypnotizing whisper of satan (nazgh alshayțān) infused into the soul (QS. 7:200, QS. 12: 100, QS. 17: 53, QS. 41: 36).

12. Misperception (QS. 3: 154, QS. 6: 148, QS. 18: 35-36, QS. 53: 2835).

13. Sinful deed(s) especially from major sins specifically stated: (1) unlawful sexual intercourse (openly or secretly), (2) unfair oppression, (3) polytheism (shirk), and (4) saying fabricated things about Allah of which one has no knowledge (QS. 7: 3337), (5) arrogance (QS. 27: 14).

14. Being harmed ('ifsād) ${ }^{68}$ (QS. 2: 10-16, 205, QS. 18: 94, QS. 47: 22).

15. Perceived Threat/Danger/Harm (QS. 9: 40, QS. 29; 33).

16. Consequence(s) from believing in fortune-telling e.g., in the story of Prophet Moses where the Pharoah issued law to kill all male new born babies of Israeli people (QS. 28: 4).

17. Being conspired against you (QS. 12: 1569; 16: 127; 27: 70; 29: $\left.33^{70}, 58: 10^{71}\right)$,

18. Concern over people we care (QS. 20: 4072, QS. 29: 32-33).

19. Staining virginity or chastity of a lady with fabricated allegations (QS. 19: 18-2173).

20. Inexplicable mystical experience(s) which could shake the psychological state of a person, worse more, if one is to face it alone i.e., without any social and psychological support (QS. 19: $\left.20-23^{74}\right)$.

21. Strong pain e.g., childbirth pain especially alone (QS. 19: $23^{75}$ ).

\footnotetext{
${ }^{68}$ Munir Baalbaki and Rohi Baalbaki, Al-Mawrid: English-Arabic and ArabicEnglish Dictionary (Lebanon, 2001).

${ }^{69}$ The story of Prophet Joseph (Y $\left.\bar{u} s u f\right)$ a.s. whereby his brothers conspired to make him out of their father's sight in Chapter 12.

${ }^{70}$ The story of Prophet Lot $(L \bar{u} t)$ a.s. whose people were going to harm his guests.

${ }^{71}$ In (QS. 58: 10) the literal term of whisper (najwā) or secret counsel corresponds conspiracy in the translation by King Fahd Complex for the Printing of the Holy Qur'an.

72 The story of Prophet Moses' (Mūsā) mother when he was a newborn.

${ }^{73}$ The story of Mary (Maryam) who is Prophet Jesus' ( $\left.{ }^{\bar{I}} \bar{s} \bar{a}\right)$ a.s. mother.

${ }^{74}$ The story of Mary (Maryam) who is Prophet Jesus' ( $\left.\bar{I} \bar{I} s \bar{a}\right)$ a.s. mother.

75 The story of Mary (Maryam) who is Prophet Jesus' ( $\left.{ }^{I} \bar{I} s \bar{a}\right)$ a.s. mother.
} 
22. Social reaction e.g., through harmful remarks or speech against someone especially when one was thought had broken any social sanctions (QS. 19: 21-3976).

23. Doubt and suspicion over one's innocency (QS. 19: 3477).

24. Parent-child love relationship leaves both parties vulnerable due to sensitivity induced by the love feeling towards certain actions from either party; be it interactive between them or independently although it is from misunderstandings only actually or from harmful deeds/remarks from other people to either parties will influence the other party too (QS. 19: 28, QS. 12: 70-86, QS. 28: 7-10, QS. 28: 8).

25. Trials of love (QS. 20:39-41). ${ }^{78}$

26. Involved in killing case (QS. 20: 40).79

27. Unattainable desire(s) (QS. 3: 176, QS. 21: 23).

28. During dying process (QS. 41: 30-31).

29. Ill-treatment from others e.g., abusive remarks (QS. 2: 263, QS. 6: 33, QS. 10:65).

30. Undergoing the Day of Judgment i.e., named as "The Day of the Greatest Horor" (Yawm al-Fazic al-Akbar) event (QS. 21: 103; 43: 66-68) that is why, among its names is "the Day of Grief" (Yawm al-Hasrat) in (QS. 19: 39).

\section{Conclusion}

Actually, there is detailed information of everything in the Qur'an on any topic we need to know about living on the Earth including about sadness. We can exhaustively explain about sadness in terms of the wisdoms of experiencing this unique emotion, specific guidance on how to face it, and many more but the space is limited and does not permit us in one paper due to restricted word count permitted by the journal. We will continue the content supplement in the Part 2.

\section{Disclosure of interest}

The authors report no conflict of interest.

\footnotetext{
${ }^{76}$ The story of Mary (Maryam) who is Prophet Jesus' ( $\left.{ }^{c} \bar{I} s \bar{a}\right)$ a.s. mother

77 The story of Mary (Maryam) who is Prophet Jesus' ( $c \bar{I} s \bar{a})$ a.s. mother

${ }^{78}$ Story of Prophet Moses $(M \bar{u} s \bar{a})$ a.s.

${ }^{79}$ Story of Prophet Moses $(M \bar{u} s \bar{a})$ a.s.
} 


\section{Acknowledgement}

The author would like to acknowledge Prof. Dr. Habeeb Rahman Ibramsa, Prof. Dr. Rahmatullah Khan, Prof. Dr. Umeed Khan, and Prof. Dr. Imtiyaz Yusuf for assisting guidance and suggestions.

\section{References}

Abu-Ras, Wahiba, Ali Gheith, and Francine Cournos. “The Imam's Role in Mental Health Promotion: A Study at 22 Mosques in New York City's Muslim Community." Journal of Muslim Mental Health 3, no. 2 (2008): 155-176. Accessed October 18, 2020.

https://www.tandfonline.com/doi/abs/10.1080/15564900802487 576.

Abu Raiya, Hisham, and Kenneth I. Pargament. "Empirically Based Psychology of Islam: Summary and Critique of the Literature." Mental Health, Religion \& Culture 14, no. 2 (February 2011): 93-115. Accessed October 18, 2020. http://www.tandfonline.com/doi/abs/10.1080/136746709034264 82.

Al-Karam, Carrie Y. Islamically Integrated Psychotherapy: Uniting Faith and Professional Practice. - Alkaram Institute. USA: Templeton Press, 2018. Accessed September 2, 2020. https://alkaraminstitute.org/islamically-integratedpsychotherapy-uniting-faith-and-professional-practice/.

Al-Muṭairī, Muḥsin Hāmid. Tafsīr Al-Qur'ān Bil Qur'ān: Ta'ṣil Wa Taqwim [Trans. Qur'anic Exegesis with the Qur'an: Origin and Correction ]. Riyadh, KSA: Dārul Tadamuriyyah, 2011.

al-Qurtubī, Abū 'Abdullah, Muḥammad ibn Ahmad ibn Abū Bakr al-Ansāri al-Khazraj̄i Shams al-Dīn. Al-Qurtubi's Exegesis: AlJāmic Li Ahkām Al-Qur'ān (Tr. The Compendium of Jurisprudential Rulings of the Qur'an). 2nd ed. Vol. 10. Cairo: Darul al-Kotob alMisriyyah, 1964. Accessed January 26, 2021. https://almaktaba.org/book/31702.

Al-Shawabkah, Murad. "Al-Tafsīr Al-Mauḍu'i (Trans. Qur'anic Thematic Exegetical Analysis)." Mawdoo3. Last modified June 16, 2020. Accessed March 18, 2021. 
https://mawdoo3.com/التفسير_الموضوعي.

Al-Ṭabarsī, Abū 'Alī, Al-Faḍl bin Al-Hasan. Majmā' Al-Bayān Fì Tafsìr Al-Qur'ān. 1st ed. Vol. 8. Beirut, Lebanon: Dār Al-cUlūm, 2005.

Alford, B. A., and A. T. Beck. The Integrative Power of Cognitive Therapy. New York: The Guilford Press, 1997.

Ali, Osman M., Glen Milstein, and Peter M. Marzuk. “The Imam's Role in Meeting the Counseling Needs of Muslim Communities in the United States." Psychiatric Services 56, no. 2 (February 2005): 202-205. Accessed January 23, 2021. https://ps.psychiatryonline.org/doi/pdf/10.1176/appi.ps.56.2.20 2.

Almaany. "Translation and Meaning of Almaani in English Arabic Terms Dictionary." Last modified 2019. https://www.almaany.com/en/dict/ar-en/al-maani/.

American Counseling Association. Integrating Spirituality and Religion into Counseling: A Guide to Competent Practice. Edited by Craig S. Cashwell and J. Scott Young. 2nd ed. Alexandria: American Counseling Association, 2011. Accessed December 2, 2020.

https://www.counseling.org/Publications/FrontMatter/72906FM.PDF.

Baalbaki, Munir, and Rohi Baalbaki. Al-Mawrid: English-Arabic and Arabic-English Dictionary. Lebanon, 2001.

Badri, Malik Babikir. Contemplation: An Islamic Psychospiritual Study . Edited by Abdul Malik Lu'lu'a. 2nd ed. Kuala Lumpur : Medeena Books, 2000.

Barnett, Jeffrey E., and W. Brad Johnson. "Integrating Spirituality and Religion Into Psychotherapy: Persistent Dilemmas, Ethical Issues, and a Proposed Decision-Making Process." Ethics \& Behavior 21, no. 2 (March 28, 2011). Accessed December 2, 2020. https://www.tandfonline.com/doi/pdf/10.1080/10508422.2011.5 51471?need Access=true.

Barry, Grace. "Personal Communication - Asking on CBT Courses for Muslim Clients." Beck Institute. USA, 2020. Accessed December 1, 2020. gmail.com.

Beck, Aaron T. "The Past and Future of Cognitive Therapy." The Journal of Psychotherapy Practice and Research 6, no. 4 (1997): 
276-284. Accessed November 16, 2020. https://www.ncbi.nlm.nih.gov/pmc/articles/PMC3330473/pdf/j p64276.pdf.

Beck Institute. "What Is Cognitive Behavior Therapy (CBT)? ." Beck Institute. Last modified 2020. Accessed November 12, 2020. https://beckinstitute.org/get-informed/what-is-cognitivetherapy/.

Beck, Judith S. Cognitive Behavior Therapy: Basics and Beyond. 2nd ed. New York: The Guilford Press, 2011.

Beck, Judith S, and Francine Broder. Coping with Depression . New Jersey, USA, 2020. Accessed November 11, 2020. https://beckinstitute.org/wp-content/uploads/2020/09/Copingwith-Depression.pdf.

Beshai, S., K. S. Dobson, and A. Adel. "Cognition and Dysphoria in Egypt and Canada: An Examination of the Cognitive Triad." Canadian Journal of Behavioural Science 44, no. 1 (2012): 29-39. Accessed October 13, 2020. https://psyc.ucalgary.ca/manageprofile/sites/psyc.ucalgary.ca. manageprofile/files/unitis/publications/15446669/Beshai_Dobson_Adel_2012.pdf.

Beshai, Shadi, Cameron M. Clark, and Keith S. Dobson. "Conceptual and Pragmatic Considerations in the Use of Cognitive-Behavioral Therapy with Muslim Clients." Cognitive Therapy and Research 37, no. 1 (February 2013): 197-206. http://link.springer.com/10.1007/s10608-012-9450-y.

Beyond Blue. “Depression vs Sadness." Beyond Blue. Last modified 2019. Accessed December 20, 2020. https://www.beyondblue.org.au/personal-best/pillar/infocus/depression-vs-sadness.

Breuninger, Matthew, Sara L Dolan, José I Padilla \& Matthew, and S S Stanford. "Psychologists and Clergy Working Together: A Collaborative Treatment Approach for Religious Clients." Journal of Spirituality in Mental Health 16, no. 3 (2014): 149-170. Accessed October 2020. https://www.tandfonline.com/action/journalInformation?journ alCode=wspi20.

Ciftci, Ayse, Nev Jones, and Patrick W Corrigan. Mental Health Stigma in the Muslim Community. Journal of Muslim Mental 
Health ISSN1556-4908. Vol. 7, 2013. Accessed December 22, 2020. http://hdl.handle.net/2027/spo.10381607.0007.102.

Conneely, Maev, Paul Higgs, and Joanna Moncrieff. "Medicalising the Moral: The Case of Depression as Revealed in Internet Blogs." Social Theory \& Health (June 4, 2020). http://link.springer.com/10.1057/s41285-020-00141-1.

Cully, J.A., and A.L. Teten. A Therapist's Guide to Brief Cognitive Behavioral Therapy. Department of Veterans Affairs South Central MIRECC. 1st ed. Houston, USA: Department of Veterans Affairs, South Central Mental Illness Research, Education, and Clinical Center (MIRECC), 2008. Accessed November 7, 2020. https://depts.washington.edu/dbpeds/therapists_guide_to_bri ef_cbtmanual.pdf.

Dein, Simon. "Religious Healing and Mental Health." Mental Health, Religion \& Culture 23, no. 8 (September 13, 2020). Accessed December 8, 2020. https://www.tandfonline.com/doi/full/10.1080/13674676.2020.1 834220.

El-Helw, Ahmed, Asim Mohiuddin, Shuhrat Dehkanov, Ahmed Farra, Hussein Maher, Wael Nafee, Ahmed Fouad, et al. "Quran for Android App." quran.com, December 31, 2017.

El-Mesawi, Mohamed El-Tahir. "Review - The Holy Qur'an Method of Qur'anic Thematic Exegetical Analysis: Critical Analysis (Ar. Murāja'ah - Manhaj Al-Tafsīr Al-Mauḍu' Li AlQur'ān Al-Karīm: Dirāsah Naqdiyyah)." At-Tajdid 15, no. 29 (2011): 231-242. https://journals.iium.edu.my/attajdid/index.php/tajdid/article/view/134/110.

England, Mary Jane, and Leslie J. Sim. "The Etiology of Depression." In Depression in Parents, Parenting, and Children: Opportunities to Improve Identification, Treatment, and Prevention, 1-488. US National Academies Press , 2009. Accessed April 5, 2021. https://www.ncbi.nlm.nih.gov/books/NBK215119/.

Fadzli Adam, and Asyraf Ab Rahman. Tafsīr and Mufassirūn: An Overview. Kuala Lumpur, Malaysia: A.S. Noordeen, 2003.

Global Health Metrics. "GBD Summaries: Depressive Disorders Level 3 Cause." The Lancet: Global Burden of Diseases 2019 (2020): 1-2. Accessed January 7, 2021. https://www.thelancet.com/pb- 
assets/Lancet/gbd/summaries/diseases/depressivedisorders.pdf.

Gloster, Andrew T., Demetris Lamnisos, Jelena Lubenko, Giovambattista Presti, Valeria Squatrito, Marios Constantinou, Christiana Nicolaou, et al. "Impact of COVID-19 Pandemic on Mental Health: An International Study." Edited by Joel Msafiri Francis. PLOS ONE 15, no. 12 (December 31, 2020): e0244809. https://dx.plos.org/10.1371/journal.pone.0244809.

Hamdan, Aisha. "Cognitive Restructuring: An Islamic Perspective." Journal of Muslim Mental Health 3, no. 1 (March 2008): 99-116.

Haque, Amber, and Hooman Keshavarzi. "Integrating Indigenous Healing Methods in Therapy: Muslim Beliefs and Practices." International Journal of Culture and Mental Health 7, no. 3 (2014): 297-314. Accessed

October

18 , 2020.

https://www.tandfonline.com/doi/abs/10.1080/17542863.2013.7 94249.

Hayes, Steven C., and Stefan G. Hofmann. "The Third Wave of Cognitive Behavioral Therapy and the Rise of Process-Based Care." World Psychiatry 16, no. 3 (October 1, 2017): 245-246. Accessed November 3 , 2020. http://doi.wiley.com/10.1002/wps.20442.

Horwitz, A.V., and J.C. Wakefield. The Loss of Sadness: How Psychiatry Transformed Normal Sorrow into Depressive Disorder. New York, USA: Oxford University Press, 2007.

Husain, Muhammad Ishrat, Imran B Chaudhry, Raza R Rahman, Munir M Hamirani, Nasir Mehmood, Peter M Haddad, John Hodsoll, Allan H Young, Farooq Naeem, and Nusrat Husain. "Pilot Study of a Culturally Adapted Psychoeducation (CaPE) Intervention for Bipolar Disorder in Pakistan." Int J Bipolar Disord 5 (2017): 3. Accessed October 19, 2020. http://www.randomisation.com.

Ibnu al-Qayyim Al-Jawzi, Shams al-Dīn, Abū 'Abd Allah, Muhammad ibn 'Abī Bakr ibn Ayyūb al-Zurcī al-Dimashqī alHanbalī (1292-1350CE/691-751AH). Raudah Al-Muhibbìn Wa Nuzhat Al-Mushtāqīn (Trans. My. Taman Orang-Orang Yang Mencintai Dan Memendam Rindu/En. Love and Missing Feelings in the Qur'an and Sunnah). Edited by Tr. Kathur Suhardi. 2nd 
ed. Jakarta, Indonesia: Darul Falah, 1997.

Khattab, Mustafa. "The Clear Qur'an." Quran for Android.

Koenig, Harold G., and David B. Larson. "Religion and Mental

Health: Evidence for an Association." International Review of Psychiatry, 2001.

Koenig, Harold G., Faten Al Zaben, and Doaa Ahmed Khalifa. "Religion, Spirituality and Mental Health in the West and the Middle East." Asian Journal of Psychiatry 5, no. 2 (June 2012): 180-182. Accessed December 26, 2020. https://pubmed.ncbi.nlm.nih.gov/22813665/.

Laird, Lance D, Mona M Amer, and Elizabeth D Barnett. "Muslim Patients and Health Disparities in the UK and the US." Arch Dis Child 92 (2007): 922-926. www.archdischild.com.

Lorenz, Louisa, Anne Doherty, and Patricia Casey. "The Role of Religion in Buffering the Impact of Stressful Life Events on Depressive Symptoms in Patients with Depressive Episodes or Adjustment Disorder." International Journal of Environmental Research and Public Health 16, no. 7 (April 8, 2019): 1238. https://www.mdpi.com/1660-4601/16/7/1238.

Malone, Joanna, and Anna Dadswell. "The Role of Religion, Spirituality and/or Belief in Positive Ageing for Older Adults." Geriatrics 3, no. 28 (2018): 1-16. Accessed October 23, 2020. www.mdpi.com/journal/geriatrics.

Meer, Shaista, and Ghazala Mir. "Muslims and Depression: The Role of Religious Beliefs in Therapy." Journal of Integrative Psychology and Therapeutics 2, no. 1 (2014). Accessed November 30, 2020. https://www.hoajonline.com/journals/pdf/2054-47232-2.pdf.

Mir, Ghazala, Ruqayyah Ghani, Shaista Meer, and Gul Hussain. "Delivering a Culturally Adapted Therapy for Muslim Clients with Depression." The Cognitive Behaviour Therapist 12 (April 12, 2019): e26.

https://www.cambridge.org/core/product/identifier/S1754470X 19000059/type/journal_article.

Mitha, Karim. "Conceptualising and Addressing Mental Disorders amongst Muslim Communities: Approaches from the Islamic Golden Age." Transcultural Psychiatry 57, no. 6 (December 15, 2020):

763-774. 
http://journals.sagepub.com/doi/10.1177/1363461520962603.

Mohammad Saleh Algahtani, Haifa, Abdullah Almulhim, Fatema Ali AlNajjar, Mazen Khalil Ali, Muhammad Irfan, Muhammad Ayub, and Farooq Naeem. "Cultural Adaptation of Cognitive Behavioural Therapy (CBT) for Patients with Depression and Anxiety in Saudi Arabia and Bahrain: A Qualitative Study Exploring Views of Patients, Carers, and Mental Health Professionals" 12 (2020): 1-17. Accessed October 19 , 2020. https://www.cambridge.org/core/terms.https://doi.org/10.1017 /S1754470X1900028XDownloadedfromhttps://www.cambridge .org/core.

Muslim, Musțafā. Mabāhnits Fi Al-Tafsīr Al-Mawdūūi [Tr. Researches in Exegetical Thematic Analysis Methodology]. Damascus, Syria: Darul Qalam, 1989.

Naeem, Farooq, Muhammad Ayub, David Kingdon, and Mary Gobbi. "Views of Depressed Patients in Pakistan Concerning Their Illness, Its Causes, and Treatments." Qualitative Health Research 22, no. 8 (August 15, 2012). Accessed December 21, 2020.

https://journals.sagepub.com/doi/pdf/10.1177/10497323124502 12.

Naeem, Farooq, Peter Phiri, Tariq Munshi, Shanaya Rathod, Muhhhamad Ayub, Mary Gobbi, and David Kingdon. "Using Cognitive Behaviour Therapy with South Asian Muslims: Findings from the Culturally Sensitive CBT Project" 27, no. 3 (2015): 233-246. Accessed December 21, 2020. https://doi.org/10.3109/09540261.2015.1067598.

Noel, Xavier, Mahesh Menon, Pierre Maurage, Daniel David, Ioana Cristea, and Stefan G Hofmann. "Why Cognitive Behavioral Therapy Is the Current Gold Standard of Psychotherapy." Frontiers in Psychiatry 9 (2018): 1-3. Accessed November 10, 2020. www.frontiersin.org.

O'Sullivan, Candice. "The Psychosocial Determinants of Depression." The Journal of Nervous and Mental Disease 192, no. 9 (September 2004): 585-594. Accessed October 21, 2020. http://journals.lww.com/00005053-200409000-00002.

Palgi, Yuval, Amit Shrira, Lia Ring, Ehud Bodner, Sharon Avidor, 
Yoav Bergman, Sara Cohen-Fridel, Shoshi Keisari, and Yaakov Hoffman. "The Loneliness Pandemic: Loneliness and Other Concomitants of Depression, Anxiety and Their Comorbidity during the COVID-19 Outbreak." Journal of Affective Disorders 275 (October 2020):

109-111. https://linkinghub.elsevier.com/retrieve/pii/S016503272032394 6.

Pargament, Kenneth, Margaret Feuille, and Donna Burdzy. "The Brief RCOPE: Current Psychometric Status of a Short Measure of Religious Coping" 2 (2011): 51-76. Accessed October 21, 2020. www.mdpi.com/journal/religionsArticle.

Pearce, Michelle J., Harold G. Koenig, Clive J. Robins, Bruce Nelson, Sally F. Shaw, Harvey J. Cohen, and Michael B. King. “Religiously Integrated Cognitive Behavioral Therapy: A New Method of Treatment for Major Depression in Patients with Chronic Medical Illness." Psychotherapy 52, no. 1 (2015). Accessed December 2020.

https://doi.apa.org/doiLanding?doi=10.1037\%2Fa0036448.

Pulcu, Erdem, Roland Zahn, and Rebecca Elliott. "The Role of SelfBlaming Moral Emotions in Major Depression and Their Impact on Social-Economical Decision Making." Frontiers in Psychology 4

http://journal.frontiersin.org/article/10.3389/fpsyg.2013.00310/a bstract.

Rathod, Shanaya. "Contemporary Psychotherapy and Cultural Adaptations." Journal of Contemporary Psychotherapy 47, no. 2 (June 26, 2017).

Rector, Neil A. Cognitive-Behavioural Therapy: An Information Guide. Canada: Centre for Addiction and Mental Health, 2010. Accessed August 11, 2020. https://www.camh.ca//media/files/guides-and-publications/cbt-guide-en.pdf.

Riehm, Kira E., Savannah G. Brenneke, Leslie B. Adams, Donya Gilan, Klaus Lieb, Angela M. Kunzler, Emily J. Smail, et al. "Association between Psychological Resilience and Changes in Mental Distress during the COVID-19 Pandemic." Journal of Affective Disorders 282 (March 2021): 381-385. https://linkinghub.elsevier.com/retrieve/pii/S016503272033161 $\mathrm{X}$. 
Sabry, Walaa M, and Adarsh Vohra. "Role of Islam in the Management of Psychiatric Disorders." Indian Journal of Psychiatry 55, no. 6 (2013): 205-214. Accessed November 30, 2020.

http://www.indianjpsychiatry.org/text.asp?2013/55/6/205/1055 34.

Saeed, Sohaib. "Thematic Tafsir Methodology." Quranica. Last modified 2012. Accessed December 23, 2020. http://quranica.com/thematic-tafsir-methodology/.

Seritan, Andreea L. "The Loss of Sadness: How Psychiatry Transformed Normal Sorrow Into Depressive Disorderby Allan V. Horwitz and Jerome C. Wakefield. New York, Oxford University Press, 2007, 312 Pp., \$29.95." American Journal of Psychiatry 164, no. 11 (November 2007): 1764-1765. http://psychiatryonline.org/doi/abs/10.1176/appi.ajp.2007.0708 1263.

Shah, Ashiq Ali. "Psychotherapy in Vacuum or Reality: Secular or Islamic Psychotherapy with Muslim Clients." Pakistan Journal of Social and Clinical Psychology 3, no. 1-2 (2005).

Taheri-Kharameh, Zahra, Hadi Zamanian, Ali Montazeri, Azadeh Asgarian, and Roya Esbiri. "Negative Religious Coping, Positive Religious Coping, and Quality of Life Among Hemodialysis Patients." Nephrourol Mon 8, no. 6 (2016): 38009. Accessed December 22, 2020. https://www.ncbi.nlm.nih.gov/pmc/articles/PMC5120233/pdf/ num-08-06-38009.pdf.

Taquet, Maxime, Sierra Luciano, John R Geddes, and Paul J Harrison. "Bidirectional Associations between COVID-19 and Psychiatric Disorder: Retrospective Cohort Studies of 62354 COVID-19 Cases in the USA." The Lancet Psychiatry 8, no. 2 (February 2021). Accessed January 26, 2021. https://www.thelancet.com/action/showPdf?pii=S22150366\%2820\%2930462-4.

Thakura, Vikram, and Anu Jain. "COVID 2019-Suicides: A Global Psychological Pandemic." Brain, Behavior, and Immunity 88 (2020): 952-953. Accessed November 6, 2020. https://www.ncbi.nlm.nih.gov/pmc/articles/PMC7177120/pdf/ main.pdf. 
Vieten, Cassandra, Shelley Scammell, Ron Pilato, Ingrid Ammondson, Kenneth I. Pargament, and David Lukoff. "Spiritual and Religious Competencies for Psychologists." Psychology of Religion and Spirituality 5, no. 3 (2013): 129-144. http://doi.apa.org/getdoi.cfm?doi=10.1037/a0032699.

Walters, Scott, T., and Melanie E. Bennett. "Assesing Clients' Spirituality and Religious Behavior: Recommendations for Research and Practice in Mental Health." The Behavior Therapist 23, no. 4 (2000): 79-90. 